\title{
The Cult of Mediocrity
}

\author{
Giovanni A. Fava \\ Department of Psychology, University of Bologna, Bologna, Italy; Department of Psychiatry, \\ State University of New York at Buffalo, Buffalo, N.Y., USA
}

In several European countries, research progress is hindered by insufficient funding, lack of competing opportunities and the control of special interest groups, which disregard scientific merit and clinical value [1]. In Europe, these groups tend to control the mechanisms of academic promotion and feel threatened by talented and independent researchers who would unmask their clinical and scientific inadequacies. A conversation with an academic colleague was particularly revealing in this sense. When I asked him why he preferred to support a mediocre clinical scientist instead of a very talented researcher, he warned me about the destabilizing effects that talent could entail on academic assets. This widespread cult of mediocrity plays a major role in the brain drain to the USA, which afflicts European science in all fields and causes an immense loss in terms of education investments and technological progress [2].

North America has provided a traditional shelter for young European scientists (let us just think of the European scientific migration to Canada in the late forties and early fifties). However, the cult of mediocrity is rapidly expanding there too. The root of the phenomenon is not simply the need the academic establishment has of having fawning supporters who would never challenge authorities. It is in the special interest groups which are the gatekeepers of corporate interest in scientific information [3]. Their members act as editors, reviewers and consultants to medical journals and nonprofit research organizations, with the task of systematically preventing dissemination of data and ideas which may be in conflict with their spe- cial interests. Antonuccio et al. [4] provide a timely illustration of the dangers of corporate-driven, constrained clinical models in American mental health.

Mediocrity supports the power structure, which, in turn, rewards it adequately. An example may be provided by the interface between authorship, industry and science in the domain of therapeutics [5, 6]. Mediocre investigators would not object to ghostwriting and industry-controlled analysis of data, in what has been defined as 'a business adopting the appearance of a science' [5, p. 27]. The industry, in turn, could reward the investigator not only in financial terms, but also in scientific prestige. It gets, in fact, its prodigal experts into leading roles in journals, medical associations and scientific meetings, whereas it provides the appropriate degree of retaliation to outliers.

The mechanisms are those outlined by Chomsky [7]: engineering opinions, public relations industry and marginalization of dissident culture. The same mechanisms may be used in academic life, particularly in Europe.

Why is talent so threatening? Because it is frequently associated with independent thinking, which undermines the power structure. And even when a talented researcher has apparently accepted to sell his or her independence, some uncertainties remain, while mediocrity assures lifelong commitment.

Fighting mediocrity is very difficult, since we are surrounded by increasing levels of mediocrity on TV, newspapers, magazines and movies. It affects culture, politics and arts, not only science. Yet, I believe that the reward of

\section{KARGER \\ Fax +41613061234 \\ E-Mail karger@karger.ch \\ www.karger.com

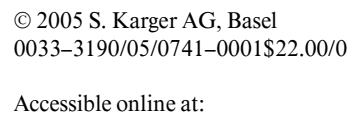

Giovanni A. Fava, MD
Department of Psychology, University of Bologna
Viale Berti Pichat 5
IT-40127 Bologna (Italy)
Fax+39051 243086, E-Mail giovanniandrea.fava@unibo.it 
fighting mediocrity may be immense in terms of scientific wealth of a nation. Looking for talent, innovations and unconventional thinking is indeed a mission of this journal [8]. In this issue, Richard Balon [9] attempts to extract some clinical implications of papers that were published in Psychotherapy and Psychosomatics in 2004. A new section, specifically dedicated to innovations, is now launched [10]. The outcome of a journal is the result of a collective effort, which involves the Editorial Board, the Assistant Editors and the external reviewers. They are the ones who helped innovations, instead of suppressing them, as often takes place in the peer review process. In the Appendix, the contribution of external reviewers during 2004 is gratefully acknowledged.

Fortunately, the widespread cult of mediocrity is unable to suppress talent, originality and dissent. There is plenty of investigators who are not afraid of swimming against the tide of conventional wisdom. And many readers do not buy everything that is offered by propaganda, but keep a skeptical and balanced attitude. What is important for both (researchers and readers) is to break isolation. This is what this journal is aimed at.

\section{Appendix}

The following experts reviewed our papers during 2004. They all disclosed potential conflicts of interest in reviewing the papers, as members of the editorial board did. The editor has no conflict of interest to declare in 2004.

Ananth J. (Torrance, Calif., USA); Bagby M. (Toronto, Canada); Bakker A. (Leidschendam, The Netherlands); Battaglia M. (Milano, Italy); Belaise C. (Modena, Italy); Benazzi F. (Forlì, Italy); Bouvard M. (Chambéry, France); Büchi S. (Zürich, Switzerland); Carta M.G. (Cagliari, Italy); Casper R. (Stanford, Calif.); Clarke D.M. (Clayton,
Australia); De Girolamo G. (Bologna, Italy); Delle Chiaie R. (Roma, Italy); Drummond L.M. (London, UK); Fabbri S. (Bologna, Italy); Facchinetti F. (Modena, Italy); Faravelli C. (Firenze, Italy); Farmer B. (Bergen, Norway); Fassino S. (Torino, Italy); Favaro A. (Padova, Italy); Gaudiano B. (Providence, R.I.); Grabe H.J. (Stralsund, Germany); Grace S.L.L. (Toronto, Canada); Grassi L. (Ferrara, Italy); Grossi G. (Stockholm, Sweden); Guidi J. (Bologna, Italy); Harvey B.H. (Potchefstroom, South Africa); Healy D. (Bangor, UK); Henningsen F. (Heidelberg, Germany); Hoglend P. (Oslo, Norway); Hoyer J. (Dresden, Germany); Jaeger B. (Hannover, Germany); Jorgensen R.S. (Syracuse, N.Y., USA); Keuthen N.J. (Charleston, Mass., USA); Labbate L. (Charleston, S.C., USA); Lam D. (London, UK); Levenstein S. (Roma, Italy); Linden M. (Berlin, Germany); Linley A. (Leicester, UK); Lumley M.A. (Detroit, Mich., USA); Majani G. (Pavia, Italy); Mangweth B. (Innsbruck, Austria); Mataix-Cols D. (London, UK); McLeod A. (Egham,UK); Molinari E. (Milano, Italy); Monari P. (Bologna, Italy); Moncrieff J. (London, UK); Morosini P.L. (Roma, Italy); Mota Cardoso R. (Porto, Portugal); Nierenberg A. (Boston, Mass., USA); Ottolini F. (Modena, Italy); Pariante C. (London, UK); Paykel E.S. (Cambridge, UK); Petersen T. (Boston, Mass., USA); Picardi A. (Roma, Italy); Porcelli P. (Castellana Grotte, Italy); Rafanelli C. (Bologna, Italy); Remschmidt H. (Berlin, Germany); Rigatelli M. (Modena, Italy); Roncuzzi R. (Bologna, Italy); Rumpf H.J. (Lübeck, Germany); Salmaso L. (Padova, Italy); Schadè A. (Amsterdam, The Netherlands); Schneider G. (Münster, Germany); Schochinger H. (Trier, Germany); Schore A.N. (Northridge, Calif., USA); Sharpe L. (Sydney, Australia); Sirri L. (Bologna, Italy); Smith A.R. (East Lansing, Mich., USA); Sobrinho L. (Lisboa, Portugal); Sondegaard P. (Stockholm, Sweden); Sonino N. (Padova, Italy); Stangier U. (Frankfurt, Germany); Tansella M. (Verona, Italy); Titelman D. (Stockholm, Sweden); Tomba E. (Bologna, Italy); Tossani E. (Boston, Mass., USA); Trijsburg R.W. (Rotterdam, The Netherlands); Van Houdenhove B. (Leuven, Belgium); Van Hout M. (Enschede, The Netherlands); Vieta E. (Barcelona, Spain); Williams S. (New Haven, Conn., USA); Zachariae R. (Aarhus, Denmark); Zimmermann C. (Verona, Italy).

The Journal's impact factor has increased again in 2003 (3.95). This places Psychotherapy and Psychosomatics as 11th in the SCI psychiatry ranking and as 4th in the SCI psychology ranking.

\section{References}

$>1$ Fava GA, Ottolini F: International trends in psychiatric research. Curr Opin Psychiatry 2004;17:283-287.

2 How to plug Europe's brain drain. Time, 19 January 2004, pp 32-39.

$>3$ Fava GA: Conflict of interest and special interest groups. Psychother Psychosom 2001;70: $1-5$.

4 Antonuccio DO, Danton WG, McClanahan TM: Psychology in the prescription era. Am Psychol 2003;58:1028-1043.
5 Healy D, Cattel D: Interface between authorship, industry and science in the domain of therapeutics. Br J Psychiatry 2003;183:22-27.

66 Bichkowsky SS, Jewesson PJ: Industry sponsorship and authorship of clinical trials over 20 years. Ann Pharmacother 2004;38:579-585.

7 Chomsky N: Media Control: The Spectacular Achievements of Propaganda. New York, Seven Stories, 1997
8 Fava GA: Conflict of interest in psychopharmacology: Can Dr Jekyll still control Mr Hyde? Psychother Psychosom 2004; 73:1-4.

$\checkmark 9$ Balon R: Reflections on relevance: Psychotherapy and Psychosomatics in 2004. Psychother Psychosom 2005;74:3-9.

10 Fava GA, Ruini C, Rafanelli C, Finos L, Salmaso L, Mangelli L, Sirigatti S: Well-being therapy of generalized anxiety disorder. Psychother Psychosom 2005;74:26-30. 